U.S. Department of the Interior

U.S. Geological Survey

\title{
Klamath River Basin Hydrologic Conditions Prior to the September 2002 Die-Off of Salmon and Steelhead
}

Water-Resources Investigations Report 03-4099 

U.S. Department of the Interior

U.S. Geological Survey

\section{Klamath River Basin Hydrologic Conditions Prior to the September 2002 Die-Off of Salmon and Steelhead}

By DENNIS D. LYNCH and JOHN C. RISLEY

Water-Resources Investigations Report 03-4099 


\section{U. S. DEPARTMENT OF THE INTERIOR \\ GALE A. NORTON, Secretary}

\section{U.S. GEOLOGICAL SURVEY}

CHARLES G. GROAT, Director

The use of trade, product, or firm names in this publication is for descriptive purposes only and does not imply endorsement by the U.S. Government.

For additional information:

\section{District Chief}

U.S. Geological Survey 10615 S.E. Cherry Blossom Dr.

Portland, OR 97216-3159

E-mail: info-or@usgs.gov

Internet: http://oregon.usgs.gov
Copies of this report may be purchased from:

USGS Information Services

Box 25286, Federal Center

Denver, CO 80225-0286

Telephone: 1-888-ASK-USGS

Suggested citation:

Lynch, D.D. and Risley, J.C., 2003, Klamath River Basin hydrologic conditions prior to the September 2002

die-off of salmon and steelhead: U.S. Geological Survey Water-Resources Investigations Report 03-4099, 10 p. 


\section{CONTENTS}

Abstract
Introduction
Upper Klamath Lake Inflows and Lake Water Levels
Upper Klamath Lake Outflows
Diversions from the Trinity River Basin
Flows in Middle and Lower Klamath Basin
Ground-Water Conditions in the Upper Klamath Basin
Water Temperature
Summary
References Cited

\section{FIGURES}

1. Map showing the location of selected streamflow and temperature monitoring sites in the Klamath and Rogue River Basins

2. Graph showing showing relation between average flows for September 1-24, 2002, and for the 1960 to 2002 September period of record at locations along the Klamath River

3. Water-level hydrograph from a USGS observation well in the Upper Klamath Lake Basin, Oregon ...............7

4. Graph showing August and September 2002 daily water temperatures in the Klamath River at Orleans, California (USGS station number 11523000)

\section{TABLES}

1. September flow conditions in the Klamath and Trinity River Basins ...................................................

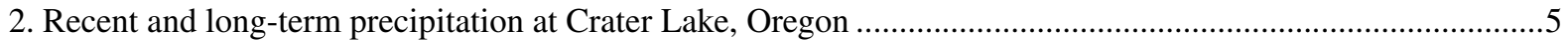

3. Estimated October mean ground-water discharge above and below the John C. Boyle Reservoir on the Klamath River and from the Spring Creek area near Chiloquin, Oregon, 1999-2002...

4. Recent and long-term daily maximum water temperature conditions on the Rogue River near Agness, Oregon

5. Recent and long-term daily maximum air temperature conditions in Orleans and Yreka, California................8

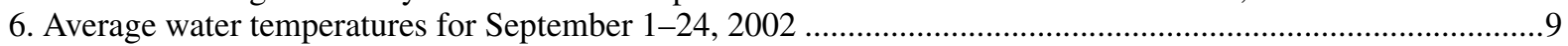


CONVERSION FACTORS AND VERTICAL DATUM

\begin{tabular}{rll}
\hline Multiply & \multicolumn{1}{c}{ By } & To obtain \\
\hline foot $(\mathrm{ft})$ & 0.3048 & meter $(\mathrm{m})$ \\
mile $(\mathrm{mi})$ & 1.609 & kilometer $(\mathrm{km})$ \\
acre & 0.004047 & square kilometers $\left(\mathrm{km}^{2}\right)$ \\
square miles $\left(\mathrm{mi}^{2}\right)$ & 1.590 & square kilometers $\left(\mathrm{km}^{2}\right)$ \\
degrees Farenheit $\left({ }^{\circ} \mathrm{F}\right)$ & $\left({ }^{1}\right)$ & degrees Celsius $\left({ }^{\circ} \mathrm{C}\right)$ \\
cubic feet per second $\left(\mathrm{ft}^{3} / \mathrm{s}\right)$ & 0.02832 & cubic meters per second $\left(\mathrm{m}^{3} / \mathrm{s}\right)$ \\
\hline
\end{tabular}

${ }^{1}$ Temperature ${ }^{\circ} \mathrm{C}=\left(\right.$ temperature $\left.{ }^{\circ} \mathrm{F}-32\right) / 1.8$

Vertical coordinates in this report are referenced to the National Geodetic Vertical Datum of 1929 (NGVD of 1929). 


\section{Klamath River Basin Hydrologic Conditions Prior to the September 2002 Die-Off of Salmon and Steelhead}

\section{By Dennis D. Lynch and John C. Risley}

\section{Abstract}

More than 33,000 salmon and steelhead died in the lower Klamath River in late September 2002 on their way to spawning areas upstream. According to the California Department of Fish and Game, the cause of death was infection by protozoan and bacterial pathogens. Two factors that may have contributed to the disease incidence are low streamflow and high water temperature.

September streamflows throughout the Klamath Basin were low, among the four lowest September flows recorded on the main stem since 1960. The low streamflows were caused by below-average snowpack and long-term drought, with resulting reduced ground-water discharge to streams.

On the basis of historical climate data from the Klamath Basin and historical water temperature data from an adjacent basin, September 2002 water temperatures were above the long-term average. Temperatures in the Klamath River above the fish die-off reach exceeded 65 degrees Fahrenheit for nearly all of September; multiple days of exposure by fish to temperatures at or above that level can greatly increase disease incidence.

This report characterizes streamflow and water temperature conditions during the period leading up to the die-off and compares them to historical conditions in the Klamath River. This report is not an exploration of the causative mechanism of the die-off; rather, it is intended to provide detailed documentation of these conditions to be used by those examining the cause(s) of the die-off and to provide information that can contribute to decisions about future water management in the Klamath Basin.

\section{INTRODUCTION}

During the last week of September 2002, a minimum of 33,000 adult salmon, steelhead trout, and other fish species died in the lower 36 miles of the Klamath River (fig. 1). A survey of dead fish conducted by the California Department of Fish and Game found that, of the salmonid species, 95.2 percent were Chinook salmon, 0.5 percent were coho salmon, and 4.3 percent were steelhead trout. The cause of death was infection by the ciliated protozoan Ichthyopthirius multifilis (Ich) and the bacterial pathogen Flavobacter columnare (Columnaris). Although both pathogens commonly occur naturally worldwide and are always present in the Klamath River and other aquatic systems, high water temperature, low flow, and crowding provided conditions favorable to their rapid proliferation and transmission (California Department of Fish and Game, 2003).

Soon after the September 2002 die-off, numerous reports and media releases attempted to describe the hydrologic conditions leading up to the event. Some of the descriptions were based on data that were incomplete, unreviewed, or not sufficiently accurate for the analyses being done. The purpose of this report is to provide a detailed documentation of these conditions, using finalized data of known and appropriate quality, to be used by those exploring the causes of the die-off and to provide information that can contribute to future decisions about water management in the Klamath Basin. 


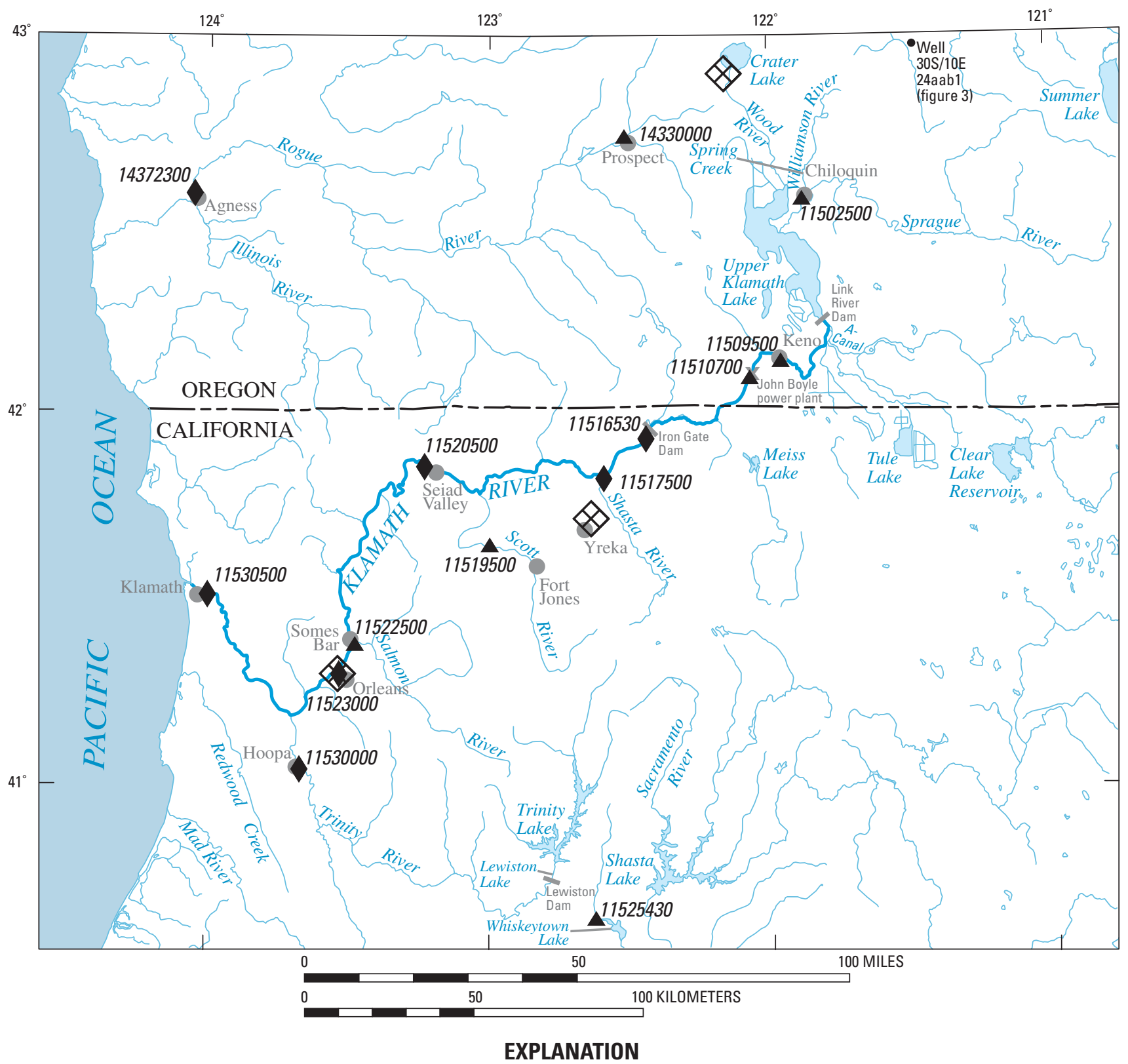

14330000 Flow station and number

14330000 Rogue River below Prospect

11502500 Williamson River near Chiloquin (inflow to Upper Klamath Lake)

11509500 Klamath River at Keno (below Upper Klamath Lake)

11510700 Klamath River below John C. Boyle Powerplant 11516530 Klamath River below Iron Gate Dam 11517500 Shasta River near Yreka 11519500 Scott River near Fort Jones 11520500 Klamath River near Seiad Valley 11522500 Salmon River at Somes Bar 11523000 Klamath River at Orleans 11525430 Judge Francis Carr Powerplant near French Gulch

11530500 Klamath River near Klamath 11530000 Trinity River at Hoopa

11517500 Water temperature station and number 14372300 Rogue River near Agness 11516530 Klamath River below Iron Gate Dam 11517500 Shasta River near Yreka 11520500 Klamath River at Seiad Valley 11523000 Klamath River at Orleans 11530000 Trinity River at Hoopa

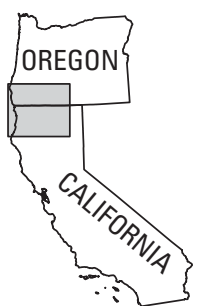

Figure 1. Selected streamflow and temperature monitoring sites in the Klamath and Rogue River Basins. 
This report presents data on streamflows, Upper Klamath Lake levels, ground-water conditions, and air and water temperatures in the Klamath River Basin during September 1-24, 2002, the period preceding the peak of the fish die-off, and provides a historical perspective on the data. Data in the report are from the U.S. Geological Survey (USGS), Western Regional Climate Center, and Bureau of Reclamation.

USGS streamflow records are published annually in data reports for each State. The accuracy of USGS streamflow records can vary from one site to another and from year to year, depending on factors involved with data collection and analysis. The accuracy of the records partly depends on the accuracy of the instantaneous measurements of streamflow made at each streamflow gaging station every $4-8$ weeks by a hydrologic technician. Accuracy decreases under difficult conditions, such as an uneven channel bottom, shallow water, dense aquatic vegetation, and slow water velocity. In addition, the accuracy of records partly depends on the stability of the "rating curve," which is the mathematical relation between measured instantaneous streamflow and water level. This relation is used to convert water-level data collected continuously at each gage to computed streamflow. Where the channel is unstable the rating curve will be constantly changing, and the computed streamflows can be unreliable. Channels with bottom sediments that are eroding, shifting or infilling, produce unstable rating curves. An unstable, sandy channel bed and large tidal fluctuations at the USGS streamflow gaging station Klamath River near Klamath, California (station number 11530500), near the river's mouth sometimes result in unreliable (greater than 15 percent error) computed streamflow records. Consequently, data from that gage are not included in this analysis.

\section{UPPER KLAMATH LAKE INFLOWS AND LAKE WATER LEVELS}

Upper Klamath Lake is the primary source of water in the Bureau of Reclamation's Klamath Project. Its surface area is large (about $130 \mathrm{mi}^{2}$ ), but it is a very shallow lake, averaging about $8 \mathrm{ft}$ (U.S. Army Corps of Engineers, 1979). Inflows to Upper Klamath Lake are mainly from the Williamson and Wood Rivers (which are primarily ground-water fed streams for most of the year), and from several hundred cubic feet per second (cfs) of ground water that directly enters the lake via springs and seeps. Average annual evaporation from the lake is about 40 inches (Hubbard, 1970). Because the lake's surface area is so large, evaporation from the lake represents a significant loss of water. Outflows from Upper Klamath Lake are primarily over the Link River Dam into the Klamath River and through the A-Canal, which is the primary conveyance of irrigation water for the Klamath Project. Many management decisions in the basin revolve around balancing the amount of water (1) passed over the Link River Dam for endangered salmon in the lower Klamath River, (2) delivered through the A-Canal to irrigate about 185,000 acres, (3) retained in Upper Klamath Lake to protect habitat for two endangered sucker fish species, (4) used for hydroelectric power production, (5) released for flood control, and (6) needed for the wildlife refuges (Jim Bryant, Bureau of Reclamation, Klamath Falls, Oregon, written commun., 2002).

September 1-24, 2002, streamflows into Upper Klamath Lake via the Williamson River (table 1, fig. 1) averaged $414 \mathrm{cfs}$, which was only 76 percent of the long-term (1960-2002) September mean monthly flow of $543 \mathrm{cfs}$. Since 1960, there have been only two Septembers with lower flows, and these occurred in 1992 and 1994 (405 and 382 cfs, respectively). Annual precipitation for water years 2001 and 2002 at Crater Lake National Park Headquarters, Oregon, was 60 and 81 percent the long-term average (table 2). Most of the streamflow in the upper basin is supported by regional ground-water discharge; consequently, streamflow in the upper basin responds to multiyear trends in precipitation. Several dry years in a row tend to produce progressively lower summer streamflows. On the basis of historical observation-well and precipitation data, ground-water levels and spring-fed streamflows in the upper Klamath River Basin typically do not increase until precipitation has returned to average or above average conditions (U.S. Geological Survey, 2001; Western Regional Climate Center, no date).

Streams in basins adjacent to the upper part of the Klamath River Basin showed similar below-average flow conditions as the Williamson River in 2002. For example, at the streamflow gage on the Rogue River near Prospect, Oregon, which is in the adjoining basin to the west, the mean daily flow for September 2002 was $698 \mathrm{cfs}$, which was 75 percent of average for the period 1969 to the present. Only three Septembers since 1969 (1992, 1994, and 2001) had flows lower than those recorded in 2002 at that gage. Regionally, below-average streamflow conditions occurred at many USGS gages in southwestern Oregon and northwestern California in the summer of 2002. 
Table 1. September Flow Conditions in the Klamath and Trinity River Basins

[Period of record for all stations is 1960-2002 unless otherwise indicated; cfs, cubic feet per second; POR, period of record; see fig. 1 for site location; source: USGS NWIS database, http://waterdata.usgs.gov/nwis/sw]

\begin{tabular}{|c|c|c|c|c|c|c|c|c|}
\hline Number & $\begin{array}{l}\text { Station } \\
\text { location }\end{array}$ & $\begin{array}{l}\text { Flow record } \\
\text { accuracy } 1\end{array}$ & $\begin{array}{l}\text { Drainage } \\
\text { area, in } \\
\text { square } \\
\text { miles }\end{array}$ & $\begin{array}{l}\text { September 1-24, } \\
2002 \text { average } \\
\text { flow, in cfs }\end{array}$ & $\begin{array}{l}\text { September } \\
2002 \text { flows, } \\
\text { percent of } \\
\text { average }^{2}\end{array}$ & $\begin{array}{l}\text { September } \\
2001 \text { average } \\
\text { flow, in } \text { cfs }^{3}\end{array}$ & $\begin{array}{c}\text { Number of } \\
\text { Septembers } \\
\text { with lower } \\
\text { flows than } \\
\text { September } \\
2002^{2}\end{array}$ & $\begin{array}{l}\text { Average } \\
\text { September } \\
\text { flows for } \\
\text { period of } \\
\text { record, in } \\
\text { cfs }^{4}\end{array}$ \\
\hline 11502500 & $\begin{array}{l}\text { Williamson River near } \\
\text { Chiloquin (inflow to Upper } \\
\text { Klamath Lake) }\end{array}$ & $\begin{array}{l}\text { Within } 10 \\
\text { percent }\end{array}$ & 3,000 & 414 & 76 & 446 & 2 & 543 \\
\hline 11509500 & $\begin{array}{l}\text { Klamath River at Keno } \\
\text { (below Upper Klamath Lake) }\end{array}$ & $\begin{array}{l}\text { Within } 10 \\
\text { percent }\end{array}$ & 3,920 & 439 & 47 & 683 & 1 & 935 \\
\hline 11510700 & $\begin{array}{l}\text { Klamath River below John C. } \\
\text { Boyle Power plant }\end{array}$ & $\begin{array}{l}\text { Within } 10 \\
\text { percent }\end{array}$ & 4,080 & 688 & 58 & 925 & 2 & 1,190 \\
\hline 11516530 & $\begin{array}{l}\text { Klamath River below Iron Gate } \\
\text { Dam (POR: 1961-2002) }\end{array}$ & $\begin{array}{l}\text { Within } 5 \\
\text { percent }\end{array}$ & 4,630 & 759 & 59 & 1,030 & 3 & 1,280 \\
\hline 11517500 & Shasta River nr Yreka & $\begin{array}{l}\text { Within } 10 \\
\text { percent }\end{array}$ & 793 & 30 & 42 & 47 & 2 & 71 \\
\hline 11519500 & Scott River nr Fort Jones & $\begin{array}{l}\text { Within } 10 \\
\text { percent }\end{array}$ & 653 & 11 & 23 & 4.4 & 4 & 48 \\
\hline 11520500 & $\begin{array}{l}\text { Klamath River near Seiad } \\
\text { Valley }\end{array}$ & $\begin{array}{l}\text { Within } 5 \\
\text { percent }\end{array}$ & 6,940 & 860 & 57 & 1,070 & 2 & 1,500 \\
\hline 11522500 & Salmon River at Somes Bar & $\begin{array}{l}\text { Within } 10 \\
\text { percent }\end{array}$ & 751 & 127 & 60 & 80 & 4 & 212 \\
\hline 11523000 & Klamath River at Orleans & $\begin{array}{l}\text { Within } 10 \\
\text { percent }\end{array}$ & 8,475 & 1,290 & 64 & 1,220 & 3 & 2,000 \\
\hline 11530000 & $\begin{array}{l}\text { Trinity River at Hoopa } \\
\text { (POR: 1964-2002) }\end{array}$ & $\begin{array}{l}\text { Within } 5 \\
\text { percent }\end{array}$ & 2,853 & 639 & 96 & 633 & 20 & 664 \\
\hline
\end{tabular}

${ }^{1}$ Flow record accuracy, as defined here, means that 95 percent of the daily flows for the 2002 water year were within the reported estimates of error. The accuracy of the 2002 flow record from the USGS gage at the Klamath River near Klamath, California (station number 11530500) was greater than 15 percent error. Hence, that station was not included in the analysis.

2"September 2002" is the period from September 1-24, 2002.

3"September 2001" is the entire month of September 2001.

4."Average September flows" are for entire months of September in the record.

The September 2002 minimum water level in Upper Klamath Lake was 4,138.6 feet above sea level (USGS station number 11507001). This is the seventh lowest September lake level recorded since 1960; meaning that September lake-levels as low as recorded in 2002 occur every 5 to 7 years under the current BOR operation of the Klamath Project. Three of the September lake levels lower than those recorded in 2002 occurred in 1991, 1992, and 1994 (4,138.2, 4,137.4, and 4,136.8 feet, respectively), which correspond to the low precipitation years of the early 1990s (Western Regional Climate Center, no date). 
Table 2. Recent and long-term annual precipitation at Crater Lake, Oregon

[Source: Western Regional Climate Center, no date; a water year is the period from October 1 through September 30]

\begin{tabular}{lcc}
\hline \multicolumn{3}{c}{ Crater Lake Precipitation } \\
\hline & $\begin{array}{c}\text { Total, } \\
\text { in inches }\end{array}$ & $\begin{array}{c}\text { Percent of } \\
\text { period of record } \\
\text { average }\end{array}$ \\
\hline Water Year 2001 & 40.2 & 60 \\
Water Year 2002 & 54.4 & 81 \\
Period of record, 1948-2002 & 67.5 & \\
\hline
\end{tabular}

${ }^{1}$ Crater Lake National Park Service Headquarters.

\section{UPPER KLAMATH LAKE OUTFLOWS}

Most surface water outflow from Upper Klamath Lake occurs at two locations. Flows continuing downstream pass through the Link River Dam. Water needed for irrigation in the Klamath Project is diverted through the A-Canal. Diversions through the A-Canal in 2002 were similar to those in many previous years when full deliveries have been sent to the Klamath Project. Typically the diversions begin in late March or early April, are at maximum in July around $940 \mathrm{cfs}$, and end in mid October. The A-Canal diversions have varied only slightly among recent years, except during 2001, when deliveries to the Klamath Project were curtailed for much of the year in order to keep water levels high enough to avoid jeopardy for the two protected sucker species. For the period September 1-24, 2002, flows in the A-Canal averaged $646 \mathrm{cfs}$ (Jim Bryant, Bureau of Reclamation, Klamath Falls, Oregon, written commun., 2002).

September 2002 outflow from Upper Klamath Lake, as measured downstream at Keno (table 1), was considerably below the long-term average. The Keno gage measures outflow from Upper Klamath Lake plus the combined effect of several irrigation withdrawals and agricultural return flows. It is a good approximation of the overall amount of water leaving Upper Klamath Lake and the Klamath Project area. Flows at the Keno gage during September 1-24, 2002, averaged $439 \mathrm{cfs}$, or 47 percent of average. This was the second lowest September flow since 1960; the lowest September flow averaged $246 \mathrm{cfs}$ in 1992.

\section{DIVERSIONS FROM THE TRINITY RIVER BASIN}

The Trinity River is a major tributary of the Klamath River; their confluence is 43 miles from the mouth and upstream of the river reach where the fish die-off occurred. Flows on the Trinity River have been regulated through storage at Trinity Lake and Lewiston Reservoir since 1960 and 1963, respectively. Since 1963, flows have been diverted from the Lewiston Reservoir out of the Trinity River Basin to the Sacramento River Basin. Diversions are sent through a tunnel to the Judge Francis Carr Powerplant at Whiskeytown Lake. For the period 1963 to 2002, the average September flow through the power plant was 1,960 cfs (measured at USGS station number 11525430). Average flow for the month of September 2001 and the period of September 1-24, 2002, was 1,630 and 1,330 cfs, respectively.

\section{FLOWS IN THE MIDDLE AND LOWER KLAMATH BASIN}

September 1-24, 2002, streamflows in the main-stem Klamath River, below Upper Klamath Lake, were well below the long-term average for Septembers over the last 40 years (table 1). From upstream to downstream along the Klamath River, September 124, 2002, flows were 58,59, 57, and 64 percent of average at USGS streamflow gaging stations below John C. Boyle Powerplant, below Iron Gate Dam, near Seiad Valley, and at Orleans, respectively (fig. 2). Although these September flows did not set new records on the main-stem Klamath, there were only a few Septembers since 1960 when flows were lower (table 1).

The gage at Orleans is about 30 miles upstream of where the die-off occurred. Streamflow for September 1-24, 2002, averaged 1,290 cfs, which was the fourth lowest September flow recorded since 1960 (table 1). Lower September flows occurred at the Orleans gage in 1991, 1992, and 2001, averaging $1,200,790$, and 1,220 cfs, respectively.

September flows at the gaging stations upstream of the Orleans gaging station (below John C. Boyle Powerplant, below Iron Gate Dam, and near Seiad Valley) were all significantly higher in 2001 than in 2002 as a result of the larger releases from Upper Klamath Lake. However, the reported September flows measured at Orleans were slightly less in 2001 (1,220 cfs) 


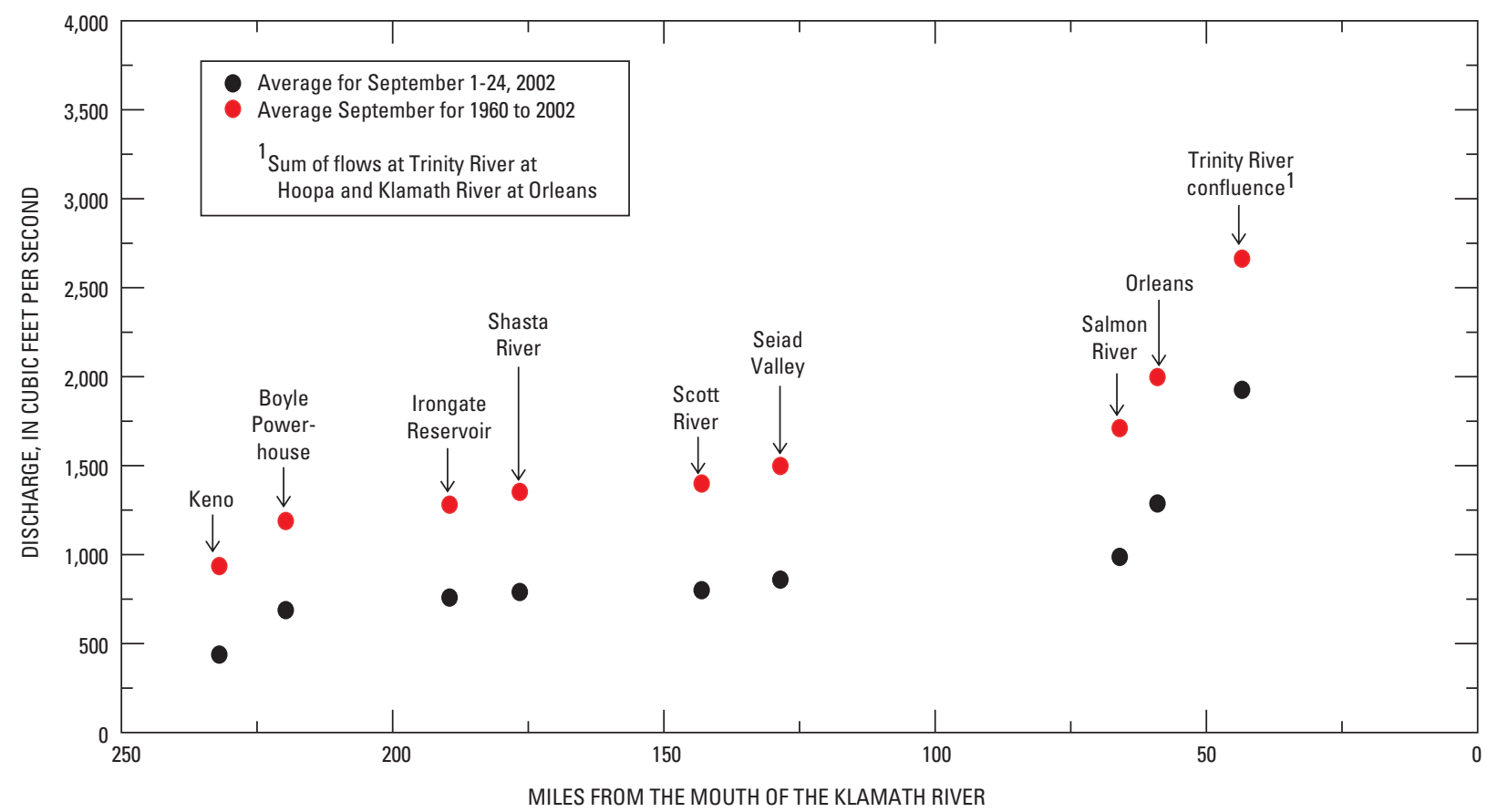

Figure 2. Relation between average flows for September 1-24, 2002, and for the 1960 to 2002 September period of record at locations along the Klamath River.

than in 2002 (1,290 cfs). Flow records at the Orleans gaging station in 2001 and 2002 were rated as having a level of accuracy within 10 percent (Friebel and others, 2002). The magnitude of error could account for the minimal measured difference between 2001 and 2002. With a plus or minus 10 percent margin of error, a value reported as 1,290 cfs is known to be between 1,160 and $1,420 \mathrm{cfs}$ with a 95 percent confidence.

Flows in most Klamath River tributaries were also low for September 1-24, 2002 (table 1). The Shasta, Scott, and Salmon Rivers flowed 43, 24, and 60 percent of average, respectively. These flows were, respectively, the 3rd, 5th, and 5th lowest recorded September flows in these rivers since 1960. In contrast to these three tributaries, flow in the regulated Trinity River recorded near Hoopa, California, was only slightly less than average (96 percent) for September 1-24, 2002.

To estimate the September 1-24, 2002 period low-flow conditions in the reach of the Klamath River where the fish die-off occurred, average flow measured during this period at the Trinity River at Hoopa and the Klamath River at Orleans gages were summed and compared with their historical average summed September flows. September 2002 flows in the reach where the die-off occurred were the sixth lowest since 1964, indicating that flows this low occur (on average) about once every 5 to 7 years. On the basis of this analysis, lower
September flows occurred in 1981, 1991, 1992, 1994, and 2001.

\section{GROUND-WATER CONDITIONS IN THE UPPER KLAMATH BASIN}

Ground-water levels in the principal recharge areas of the Upper Klamath Basin declined during the drought year of 2001 and continue to decline through water year 2002. Figure 3 shows the decline in the water-table elevation in a well located in the Upper Klamath Lake Basin approximately 30 miles east of Crater Lake over the past 2 years. The water-level hydrograph had the same trend as those from most other observation wells located throughout the region, indicating there was little ground-water recharge in the basin during both 2001 and 2002 (U.S. Geological Survey, 2001). Annual precipitation for water years 2001 and 2002 at Crater Lake National Park, Oregon, was 60 and 81 percent of the long-term average (table 2). Although precipitation during the 2002 water year was closer to average than in 2001, much of the precipitation in 2002 went toward making up a soil-moisture deficit in the Klamath Basin from the previous drought year, and thus was unavailable to recharge the principle aquifers. 


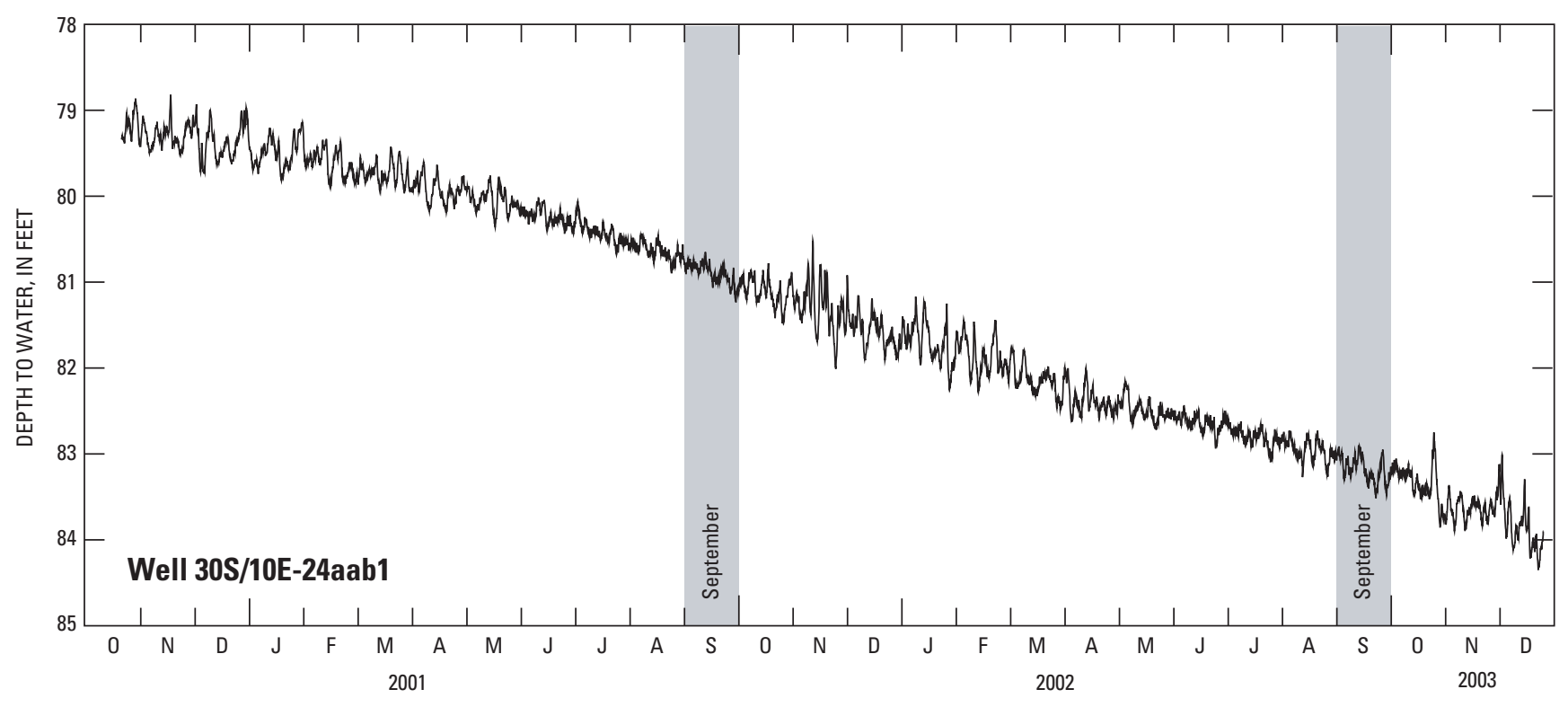

WATER YEAR

Figure 3. Water-level hydrograph from a USGS observation well in the Upper Klamath Lake Basin, Oregon. The steady decline of the water level in this well, which is unaffected by pumping of other wells, was caused by decreased ground-water recharge in the basin during the drought of 2001-02. Well location is shown on figure 1.

As ground-water levels continued to decline in 2002, ground-water discharge to springs and streams declined as well, and the effects of the previous year's drought can be seen in the lower-than-average 2002 streamflows. Data indicate that ground-water discharge to streams (baseflow) during summer and fall of 2002 was similar to or less than for the same period of 2001 in the upper basin. Estimated October mean groundwater inflows to the Klamath River and tributaries between the USGS stream-gaging stations at Keno (11509500) and below the John C. Boyle Powerplant (11510700) from 1999 to 2002 are shown in table 3. The month of October is shown in this analysis because it is a period of the year when most flow diversions for irrigation have ended and precipitation is still minimal. Storage changes in the John C. Boyle reservoir were considered in inflow estimates. Although the difference in inflow from one year to another is near or within the measurement error of these two streamflow-gaging stations, the data show a systematic decline over the 4 years.

Table 3 also shows estimated October mean inflows from Spring Creek and the region upstream and downstream of its confluence with the Williamson River near Chiloquin, Oregon. These estimates were based on data from nearby USGS gaging stations located on the Williamson River near Klamath Agency (11493500), Williamson River below Sprague River, near Chiloquin (11502500), and Sprague River near
Table 3. Estimated October mean ground-water discharge above and below the John C. Boyle Reservoir on the Klamath River and from the Spring Creek area near Chiloquin, Oregon, 1999-2002

\begin{tabular}{ccc}
\hline \multicolumn{3}{c}{$\begin{array}{c}\text { Estimated October mean ground-water inflows, } \\
\text { in cubic feet per second }\end{array}$} \\
\hline Year & $\begin{array}{c}\text { Area above and below the } \\
\text { John C. Boyle Reservoir }\end{array}$ & Spring Creek area \\
\hline 1999 & 297 & 334 \\
2000 & 290 & 309 \\
2001 & 257 & 298 \\
2002 & 241 & 294 \\
\hline
\end{tabular}

Chiloquin (11501000). Approximately 90 percent of the inflow is from Spring Creek itself, which is almost entirely ground-water discharge. A basinwide decrease in ground-water discharge in 2002 probably explains why inflow to Upper Klamath Lake was less than predicted by the BOR based on snowpack estimates alone.

On the basis of experience in geologically similar basins, such as the Deschutes River Basin to the north (Gannett and others, 2000), multiple years of normal or above-normal precipitation may be required before streamflows and spring discharges recover to predrought levels. 


\section{WATER TEMPERATURE}

The USGS has collected water temperature data at some of the flow stations in the lower Klamath River Basin. Along the Klamath River, these stations include Irongate Reservoir, Seiad Valley, Orleans, and Klamath. Water temperature data have also been collected on the Shasta River near Yreka and the Trinity River at Hoopa Valley. The period of record for these stations ranges from 17 to 21 years. All the records start in the 1960s and end in the 1970s or 1980s. Within the last few years these stations have been reactivated. However, the lack of continuity in the records makes it difficult to put the 2002 water temperature conditions into historical context to determine whether they were unusually warm.

A longer-term water temperature record exists for a station on the Rogue River near Agness, Oregon (USGS station number 14372300). The Rogue River Basin, which is the adjoining coastal basin to the north of Klamath River, is large $\left(3,939 \mathrm{mi}^{2}\right)$, and it shares similar climatic, geologic, and hydrologic features with the Klamath River Basin. Water temperatures were measured for 35 years on the Rogue River during the periods 1961-1987 and 1995-2002 (table 4). The mean daily maximum September water temperature for the 35 -year period of record at this station was $65.7^{\circ} \mathrm{F}$

Table 4. Recent and long-term daily maximum water temperature conditions on the Rogue River near Agnes, Oregon

[POR, period of record from 1961 to 2002; missing years were 1967, 1974, 1978, 1988-1994, 1996]

\begin{tabular}{|c|c|}
\hline \multicolumn{2}{|c|}{ Daily maximum water temperatures, in degrees Fahrenheit } \\
\hline September 2001 mean & 67.1 \\
\hline September 2002 mean & 67.3 \\
\hline September POR mean & 65.7 \\
\hline Percentile rank of the September 2002 mean for the POR & 80 \\
\hline
\end{tabular}

(degrees Fahrenheit). In contrast, the mean daily maximum water temperature for September 2002 was $67.3^{\circ} \mathrm{F}$. For the period of record, $67.3^{\circ} \mathrm{F}$ has a percentile rank of 80 , which means that it would likely be equaled or exceeded once every 5 years. While these temperature differences between the period of record and 2002 may seem small, small differences in temperature can affect the health of migrating salmonids when water temperatures approach chronic and acute thresholds like they periodically do in the Klamath and Rogue River Basins (Poole and others, 2001; Poole and Berman, 2001).

Stream temperatures typically fluctuate in response to changes in the weather, and they closely follow patterns of air temperature (Lewis and others, 2000; Mohseni and Stefan, 1999). Months with warmer-than-average air temperatures typically have warmer-than-average water temperatures. Consequently, long-term air temperature data in the Klamath River Basin below Upper Klamath Lake may be a surrogate for long-term water temperatures in the same region (table 5). Two climate stations are located upstream of the die-off reach in Orleans and Yreka. For the month of September 2002, average daily maximum air temperatures for these two stations had percentile ranks of 73.8 and 82.5 for the 1960 to 2002 period of record. September air temperatures in 2002 were about $2{ }^{\circ} \mathrm{F}$ higher than the long-term average (Jim Ashby, Western Regional Climate Center, Reno, Nevada, written commun., 2002).

Table 5. Recent and long-term daily maximum air temperature conditions in Orleans and Yreka, California

[POR, the period of record from 1960 to 2002, 1987 and 1993 were missing from the Yreka record; Reference: Jim Ashby, Western Regional Climate Center, 2002, Western Regional Climate Center, no date]

Daily maximum air temperatures, in degrees Fahrenheit

\begin{tabular}{|c|c|c|c|}
\hline \multicolumn{2}{|c|}{ Orleans, California } & \multicolumn{2}{|l|}{ Yreka, California } \\
\hline September 2001 mean & 87.1 & September 2001 mean & 85.7 \\
\hline September 2002 mean & 89.6 & September 2002 mean & 86.3 \\
\hline September POR mean & 87.4 & September POR mean & 82.3 \\
\hline $\begin{array}{l}\text { Percentile rank of the } \\
\text { September } 2002 \text { mean } \\
\text { for the POR }\end{array}$ & 73.8 & $\begin{array}{l}\text { Percentile rank of the } \\
\text { September } 2002 \text { mean } \\
\text { for the POR }\end{array}$ & 82.5 \\
\hline
\end{tabular}

In 2002 the USGS collected continuous water temperature data at several locations in the Klamath River Basin (table 6). The daily minimum temperature of the Klamath at Orleans, upstream from the die-off, remained above $65^{\circ} \mathrm{F}$ for the entire period of September 1-24, 2002 (fig 4). In salmonids, $65^{\circ} \mathrm{F}$ is a level at which disease rates can be severe (Poole and others, 2001). 
Table 6. Average water temperatures for September 1-24, 2002 $\left[{ }^{\circ} \mathrm{F}\right.$, degrees Fahrenheit; na, not available. Temperatures for the Upper Klamath Lake averaged from 11 monitors. Temperatures for the Trinity River confluence are calculated from a mass balance of average flows and temperatures at the Orleans and Hoopa stations]

\begin{tabular}{|c|c|c|c|}
\hline $\begin{array}{l}\text { Station } \\
\text { number }\end{array}$ & Station name & $\begin{array}{l}\text { Average of daily } \\
\text { maximum } \\
\text { temperatures, } \\
\text { in }{ }^{\circ} \mathrm{F}\end{array}$ & $\begin{array}{c}\text { Average of } \\
\text { daily } \\
\text { minimum } \\
\text { temperatures, } \\
\text { in }{ }^{0} \mathrm{~F}\end{array}$ \\
\hline na & $\begin{array}{l}\text { Upper Klamath } \\
\text { Lake }\end{array}$ & 65.3 & 61.9 \\
\hline 11516530 & $\begin{array}{l}\text { Klamath River } \\
\text { below Iron Gate } \\
\text { Dam }\end{array}$ & 66.1 & 64.6 \\
\hline 11517500 & $\begin{array}{l}\text { Shasta River near } \\
\text { Yreka }\end{array}$ & 70.0 & 59.8 \\
\hline 11520500 & $\begin{array}{l}\text { Klamath River at } \\
\text { Seiad Valley }\end{array}$ & na & na \\
\hline 11523000 & $\begin{array}{l}\text { Klamath River at } \\
\text { Orleans }\end{array}$ & 68.6 & 67.4 \\
\hline 11530000 & $\begin{array}{l}\text { Trinity River at } \\
\text { Hoopa }\end{array}$ & 68.9 & 65.5 \\
\hline na & $\begin{array}{l}\text { Trinity River } \\
\text { confluence }\end{array}$ & 68.7 & 66.8 \\
\hline
\end{tabular}

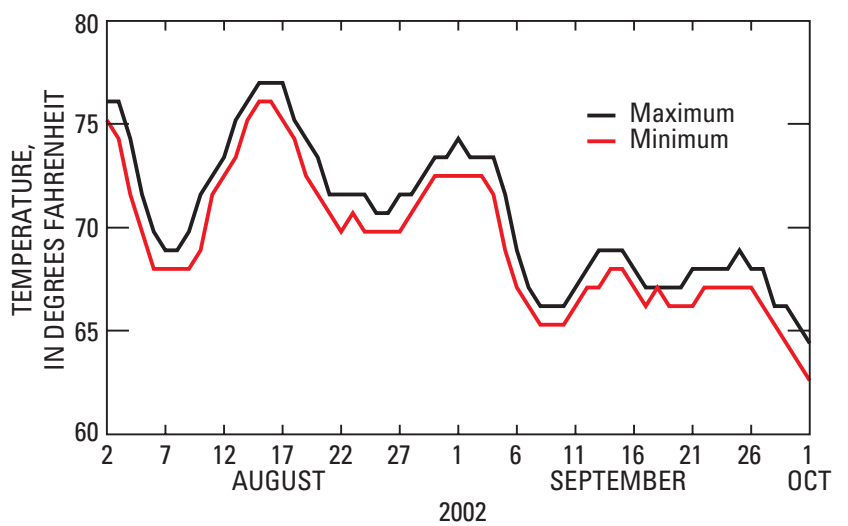

Figure 4. August and September 2002 daily water temperatures in the Klamath River at Orleans, California (USGS station number 11523000).
During the time of the fish die-off, there was concern that release of additional water from Upper Klamath Lake in September 2002 might worsen the water-temperature problem in the lower Klamath River. The 2002 water-temperature data from Upper Klamath Lake and the Klamath River at Orleans suggest that these concerns were unwarranted: Water temperatures in the lake were considerably cooler than in the river at Orleans. Daily maximum and minimum water temperatures in Upper Klamath Lake averaged 65.3 and $61.9^{\circ} \mathrm{F}$, respectively, for the period September 1-24, 2002, as compared to 68.6 and $67.4{ }^{\circ} \mathrm{F}$ in the Klamath River at Orleans. A similar temperature differential existed throughout the summer be- tween Upper Klamath Lake and the lower Klamath River, largely owing to the fact that Upper Klamath Lake has a surface elevation of about 4,140 feet, where the nights are much cooler.

It should be noted, however, that water released from the Upper Klamath Lake during the summer months typically warms along its 255 -mile course to the ocean as it comes into thermal equilibrium with the warmer air temperatures at lower elevations in the basin. Consequently, any cooling benefit of water released from Upper Klamath Lake, by the time it reaches the mouth, would probably be minimal.

\section{SUMMARY}

- September 2002 streamflows throughout the Klamath Basin were low, averaging about 57 to 64 percent of long-term averages at streamflow gaging stations on the main-stem river. In most cases, the September 2002 flows were among the four lowest September flows recorded since 1960. Similar low-flow conditions existed in Klamath River tributaries, including the Williamson (the largest tributary to Upper Klamath Lake), Shasta, Scott, and Salmon Rivers. Only the Trinity River, regulated by storage reservoirs, had near-average streamflows.

- September 2002 flows 30 miles upstream of fish die-off reach were the fourth lowest since 1960, indicating that flows this low occur (on average) about once every 10 years; lower September flows occurred in 1991, 1992, and 2001. 
- The Klamath River Basin was not the only basin experiencing low flows in southern Oregon and northern California in September of 2002. Similar conditions existed in surrounding basins, such as the Rogue River Basin in Oregon.

- Ground-water levels in the principal recharge areas of the Klamath River Basin declined during the drought year of 2001 and continued to decline through water year 2002. Although precipitation during water year 2002 was closer to average than in 2001, much of the precipitation went toward making up a soil-moisture deficit from the previous drought year. Because streams in the Klamath River Basin are fed primarily by ground water, 2002 streamflows were lower than the Bureau of Reclamation expected based on snowpack data alone. It may take multiple years of average to above average precipitation before ground-water levels, and thus streamflows, recover to predrought levels.

- Based on long-term water temperatures in the nearby Rogue River Basin and air temperatures within the Klamath River Basin, September 2002 water temperatures in the lower Klamath River were probably above average.

- Daily minimum temperatures at Klamath River at Orleans (upstream from the fish die-off reach) remained above $65^{\circ} \mathrm{F}$ during the period September $1-24,2002$, a level at which disease rates in salmonids can be severe.

- The USGS streamflow data used in this analysis came from gages for which records are estimated to be correct to within a 10 percent margin of error. The USGS gage closest to the mouth of the Klamath River was not used in the analysis because its 2001 and 2002 record had estimated erors greater than 15 percent.

\section{REFERENCES CITED}

California Department of Fish and Game, 2003, September 2002 Klamath River fishkill-Preliminary analysis of contributing factors: Redding, State of California, The Resources Agency, Department of Fish and Game, 63 p. [Also available at http://www.dfg.ca.gov/, accessed April 21, 2003]
Friebel, M.F., Freeman, L.A., Smithson, J.R., Webster, M.D., Anderson, S.W., and Pope, G.L., 2002, Water resources data, California, water year 2001, volume 2: U.S. Geological Survey Water-Data Report CA-01-2, $450 \mathrm{p}$.

Gannett, M.W., Lite, K.E., Morgan, D.S., and Collins, C.A., 2000, Ground-water hydrology of the upper Deschutes Basin, Oregon: U.S. Geological Survey Water-Resources Investigations Report 00-4162, 78 p.

Herrett, T.A., Hess, G.W., House, J.G., Ruppert, G.P., and Courts, M.L., 2002, Water resources data, Oregon, water year 2001: U.S. Geological Survey Water-Data Report OR-01-1, $430 \mathrm{p}$.

Hubbard, L.L., 1970, Water budget of Upper Klamath Lake, Southwestern Oregon: U.S. Geological Survey Hydrologic Investigations Atlas HA-351, scale 1:250,000.

Lewis, T.E., Lamphear, D.W., McCanne, D.R., Webb, A.S., Krieter, J.P., and Conroy, W.D., 2000, Regional assessment of stream temperatures across Northern California and their relationship to various landscape-level and site-specific attributes: Arcata, California, Forest Science Project, Humboldt State University Foundation, [variously paged].

Mosheni, O., and Stefan, H.G., 1999, Stream temperature/air temperature relationship-A physical interpretation: Journal of Hydrology, v. 218, p. 128-141.

Poole, G.C., Dunham, J., Hicks, M., Keenan, D., Lockwood, J., Materna, E., McCullough, D., Mebane, C., Risley, J., Sauter, S., Spalding, S., and Sturdevant, D., 2001, Technical synthesis scientific issues relating to temperature criteria for salmon, trout, and char native to the Pacific Northwest: U.S. Environmental Protection Agency, EPA 910-R-01-007, August, 2001, 21 p.

Poole, G.C., and Berman, C.H., 2001, An ecological perspective on in-stream temperature-Natural heat dynamics and mechanisms of human-caused thermal degradation: Ecological Management, no. 27, p. 787802.

U.S. Army Corps of Engineers, 1979, Klamath River Basin-Oregon-Reconnaissance report: San Francisco, U.S. Army Corps of Engineers, 175 p.

U.S. Geological Survey, 2001, Water-level measurement data for selected wells in Upper Klamath Basin, Oregon and California: http://oregon.usgs.gov/projs_dir/or180/ waterlevels/index.html, accessed on February 10, 2003.

Western Regional Climate Center, no date, Historical climate information: http://www.wrcc.dri.edu/ climsum.html, accessed on November 6, 2002. 
